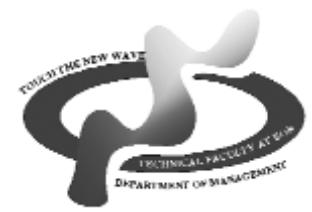

www.sjm06.com
Serbian

Journal

of

Management

\title{
THE ANALYSIS OF SCIENTIFIC-RESEARCH WORK OF GROUP OF TECHNICAL FACULTIES OF BELGRADE UNIVERSITY IN THE POST-ACCREDITATION PERIOD
}

\author{
Milica Arsić*, Nenad Milijić, Dragana Živković, Djordje Nikolić and Živan Živković \\ University of Belgrade, Technical Faculty in Bor, Vojske Jugoslavije 12, 19210 Bor, Serbia
}

(Received 28 August 2011; accepted 12 November 2011)

\begin{abstract}
This paper presents the analysis of the results of a scientific and research work for the group of technical-technological faculties, University of Belgrade, in the post-accreditation period (2008 2010), measured through a number of published papers in journals with an impact factor and citations, generated by SCOPUS database. A number of papers and a number of citations for the observed period (3 years) are presented by categories of teachers for each faculty separately. Quality Index was calculated as the ratio of cited and published papers, for each faculty, and according to the number of researchers, which eliminates the influence of the faculties' size on total results. Multicriteria PROMETHEE II - GAIA analysis defines the clusters of faculty, which determine the importance of actual contributions of technical faculties (University of Belgrade) on the way to the Shanghai list of 500 first-ranked universities in the world.
\end{abstract}

Keywords: scientific and research work, technical faculties, University of Belgrade, SCOPUS, PROMETHEE II - GAIA

\section{INTRODUCTION}

Can we manage knowledge? Knowledge is mostly cognitive and individual, and its management involves organizational changes and that is why the resistance to the concept of knowledge management occurs.
Since knowledge is recognized as a key organizational resource, knowledge management is gaining the attention. The establishment of the adequate organization that uses meaningful knowledge of its members, and creates a system of free transfer of knowledge among members of

\footnotetext{
* Corresponding author: marsic@tf.bor.ac.rs
}

DOI: $10.5937 /$ sjm1201009A 
the organization, means that knowledge management actually exists. Therefore, the knowledge management presents an explicit and systematic management of vital knowledge, which refers to the process of creation, organization, dissemination, use and exploitation of useful knowledge. In this way, the professional knowledge is being translated into the corporate knowledge that is systematically spread throughout the organization and in an appropriate way applied (Wijetunge, 2002).

Faculties and universities are institutions where the most obvious need for knowledge management exists, not only because of their activities - education of highly educated staff and dealing with scientific research, but also because of the employees, whose individual skills and competencies should be combined into a corporate knowledge.

The question is - what kind of knowledge should be managed in higher education institutions? There are four types of knowledge required for effective functioning of faculties and universities: a) internal tacit knowledge - the competence and knowledge of professors and associates, b) Internal explicit knowledge - consists of reports, guidelines, databases and any other material within the faculty c) External explicit knowledge - is a tangible material in the form of books, magazines, CDs, etc., that are created outside the faculty, and d) external tacit knowledge - the expertise and competence of persons outside the University, which in some way support the higher education institutions (Klobas, 1997; Wijetunge, 2002; Živković, et al., 2010).

Many researchers have studied the management of knowledge, types of knowledge in universities, systems that support knowledge management etc. Wijetunge (2002) in his study emphasizes the management of explicit knowledge, in order to create organizational knowledge in accordance with university reforms. Garvin (1993) argues that new ideas are essential in creating organizational knowledge and believes that such ideas are created within departments, or, on the other hand, very often acquired from the external sources. However, as Garvin (1993) says, the idea per se does not lead to any improvements in the organization, but it must be implemented in adequate procedures. Dagli et al. (2009) in their research state that the effective knowledge management leads to success of the Faculty, but suggest that it is also necessary to create tools for managing information, while Numprasertchai and Igel (2005) point out that universities must successfully create and spread new knowledge through the cooperation among its members, as well as through the cooperation with other universities - which according to them is the best way to increase the creative potential. Many researchers, such as Van Looy's (2006) and Rosell (2009), by studying the publications and patents of the university researchers confirmed their significant impact on the economy, as the conclusive evidence of knowledge management at universities.

On the base of what has been said previously, it is clear that the knowledge management at faculties and universities includes management of both explicit and tacit knowledge. Procedures and guidelines of new reforms may affect the tacit knowledge. Increased number of publications and patents in this way can be a materialization of knowledge and competencies of university teachers, ie. quantitative but also qualitative indicators of knowledge management in universities and colleges. On the base of these findings, the 
object and the purpose of this research are based - through analysis of postaccreditation results - period 2008.-2010. - in terms of number of publications and citations of teaching staff at eight faculties from the group of technical and engineering faculties of the University of Belgrade.

\section{EXPERIMENTAL}

The group of Technical and Technological Faculties, University of Belgrade, comprises eleven faculties - Faculty of Architecture, Faculty of Civil Engineering, Faculty of Electrical Engineering, Faculty of Mechanical Engineering, Faculty of Agriculture, Faculty of Mining and Geology, Faculty of Transport and Traffic Engineering, Faculty of Technology and Metallurgy, Faculty of Forestry, Technical Faculty in Bor and the Faculty of Organizational Sciences. This paper deals with data collected only for eight technical faculties of Belgrade University: Faculty of Organizational Sciences (FON), Faculty of Mining and Geology (RGF), Technology and Metallurgy (TMF), Technical Faculty in Bor (TFB), Electrical Engineering (ETF), Traffic Engineering (SF), Civil Engineering (GF) and Mechanical Engineering (MF). It employs in total 1113 teachers and staff, out of which 285 are full professors, 152 associate professors, 225 assistant professors, 359 assistants and 92 teaching associates. Data on the number and titles of the faculties' staff were taken from the official website of the University. A search of academic databases Scopus (www.scopus.com) came up to the data that these researchers published 1902 scientific papers in period after the accreditation (2008 - 2010.), and that in this three-year period, their papers were cited 11,056 times. Also, it should be emphasized that only papers published in scientific journals on SCI and JCR lists were discussed. Papers from seminars and conferences are not included. Also, as for the citations, self-citations are not included. It should be noted that this search of Scopus database was conducted in December 2010, and these results, presented in the paper, correspond to the data for that period.

\section{RESULTS AND DISCUSSION}

A number of published papers and citations in the post-accreditation period

Table1. The number of published papers and citations (self-citations excluded) at the Faculty of Organizational Sciences (2008-2010.)

\begin{tabular}{|c|c|c|c|c|c|c|c|c|c|}
\hline $\begin{array}{c}\text { Academic } \\
\text { rank }\end{array}$ & Members & $\begin{array}{c}\text { Number } \\
\text { of papers } \\
2008\end{array}$ & $\begin{array}{c}\text { Number } \\
\text { of papers } \\
2009 .\end{array}$ & $\begin{array}{c}\text { Number } \\
\text { of papers } \\
2010 .\end{array}$ & $\begin{array}{c}\text { Number } \\
\text { of papers } \\
2008- \\
2010 \\
\end{array}$ & $\begin{array}{c}\text { Number } \\
\text { of } \\
\text { citations } \\
2008 \\
\end{array}$ & $\begin{array}{c}\text { Number } \\
\text { of } \\
\text { citations } \\
2009 \\
\end{array}$ & $\begin{array}{c}\text { Number } \\
\text { of } \\
\text { citations } \\
2010 \\
\end{array}$ & 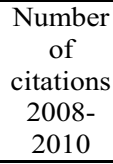 \\
\hline $\begin{array}{c}\text { Full } \\
\text { professors } \\
\text { Associate }\end{array}$ & 28 & 9 & 15 & 13 & 37 & 94 & 119 & 91 & 304 \\
\hline $\begin{array}{l}\text { professor } \\
\text { Assistant }\end{array}$ & 13 & 2 & 3 & 2 & 7 & 3 & 2 & 4 & 9 \\
\hline $\begin{array}{l}\text { professor } \\
\text { Research }\end{array}$ & 29 & 4 & 12 & 27 & 43 & 7 & 12 & 14 & 33 \\
\hline $\begin{array}{l}\text { assistant } \\
\text { Teacher }\end{array}$ & 56 & 3 & 11 & 4 & 18 & 1 & 6 & 9 & 16 \\
\hline assistant & 23 & 0 & 0 & 2 & 2 & 0 & 0 & 0 & 0 \\
\hline Total & 149 & 18 & 41 & 48 & 107 & 105 & 139 & 118 & 362 \\
\hline
\end{tabular}


according to the academic rank, for the Faculty of Organizational Sciences, are shown in Table 1. (www.fon.bg.ac.rs; www.scopus.com).

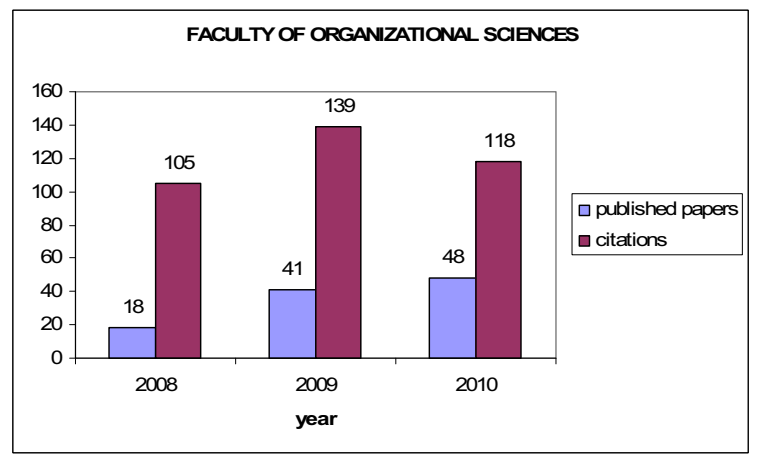

Figure 1. Published papers and citations of professors and other teaching staff at the Faculty of Organizational Sciences (period from 2008 to 2010)

Figure 1. shows the increasing trend of published papers of professors and other teaching staff of the Faculty of Organizational Sciences in the studied period. The largest contributions to the creation of such a trend have assistant professors. Full professors and assistants contributed to this trend in 2008 and 2009, while a decline in the number of their publications was recorded in 2010 . The total number of publications of associate professors and teaching assistants neither shows any contribution to the trend growth nor any contribution to the quantity of published papers, taken from the point of view of the entire collective.

A number of published papers and citations in the post-accreditation period according to the academic rank, for the Faculty of Mining and Geology, are shown in Table 2. (www.rgf.bg.ac.rs; www.scopus.com).

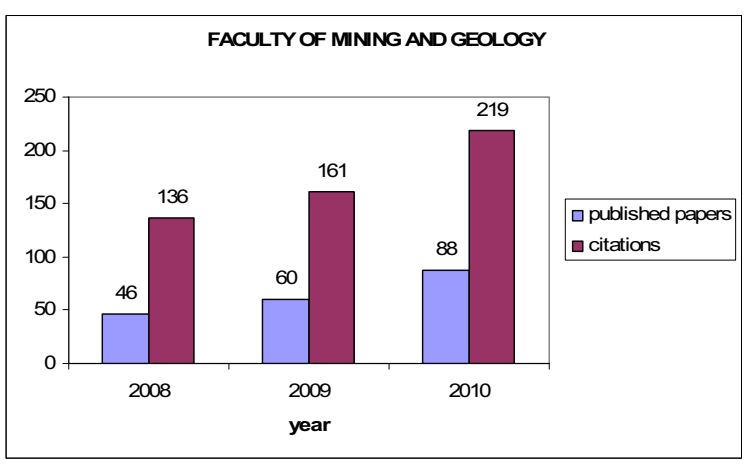

Figure 2. Published papers and citations of professors and other teaching staff at the Faculty of Mining and Geology (period from 2008 to 2010)

Figure.2. shows the increasing trend of published works of professors and other teaching staff of the Faculty of Mining and

Table 2. The number of published papers and citations (self-citations excluded) at Faculty of Mining and Geology (2008-2010.)

\begin{tabular}{|c|c|c|c|c|c|c|c|c|c|}
\hline $\begin{array}{l}\text { Academic } \\
\text { rank }\end{array}$ & Members & $\begin{array}{c}\text { Number } \\
\text { of papers } \\
2008\end{array}$ & $\begin{array}{c}\begin{array}{c}\text { Number } \\
\text { of papers }\end{array} \\
2009 .\end{array}$ & $\begin{array}{c}\begin{array}{c}\text { Number } \\
\text { of papers }\end{array} \\
2010 .\end{array}$ & $\begin{array}{c}\text { Number } \\
\text { of papers } \\
2008- \\
2010\end{array}$ & $\begin{array}{c}\text { Number } \\
\text { of } \\
\text { citations } \\
2008\end{array}$ & $\begin{array}{c}\text { Number } \\
\text { of } \\
\text { citations } \\
2009\end{array}$ & $\begin{array}{c}\text { Number } \\
\text { of } \\
\text { citations } \\
2010\end{array}$ & $\begin{array}{c}\text { Number } \\
\text { of } \\
\text { citations } \\
2008- \\
2010\end{array}$ \\
\hline $\begin{array}{c}\text { Full } \\
\text { professor }\end{array}$ & 59 & 26 & 34 & 51 & 111 & 111 & 112 & 140 & 363 \\
\hline $\begin{array}{l}\text { Associate } \\
\text { professor }\end{array}$ & 19 & 4 & 5 & 8 & 17 & 4 & 8 & 11 & 23 \\
\hline $\begin{array}{l}\text { Assistant } \\
\text { professor }\end{array}$ & 40 & 16 & 17 & 23 & 56 & 21 & 41 & 66 & 128 \\
\hline $\begin{array}{l}\text { Research } \\
\text { assistant }\end{array}$ & 13 & 0 & 3 & 6 & 9 & 0 & 0 & 2 & 2 \\
\hline assistant & 1 & 0 & 1 & 0 & 1 & 0 & 0 & 0 & 0 \\
\hline Total & 133 & 46 & 60 & 88 & 194 & 136 & 161 & 219 & 516 \\
\hline
\end{tabular}


Geology. The creation of such an increasing trend of a number of publications provide researchers of all academic ranks, except for the teacher assistants, which makes sense, because they are still young and not experienced researchers. However, quantitatively speaking, the full professors of the Faculty of Mining and Geology have the major part in contributing to the total number of publications, as well as in creating an increasing trend of the number of publications.

A number of published papers and citations in the post-accreditation period according to the academic rank, for the Faculty of Technology and Metallurgy, are shown in Table 3. (www.tmf.bg.ac.rs; www.scopus.com).

The number of publications of professors and other teaching staff of the Faculty of Technology and Metallurgy in the first two years of the studying period was increasing, while in 2010 there was recorded a slight decline compared to 2009 (Figure 3.). This decrease is slight, especially when one bears in mind the number of publications per year which is greater than at all other faculties of the observed group. In addition, the number

Table 3. The number of published papers and citations (self-citations excluded) at Faculty of Technology and Metallurgy (2008-2010.)

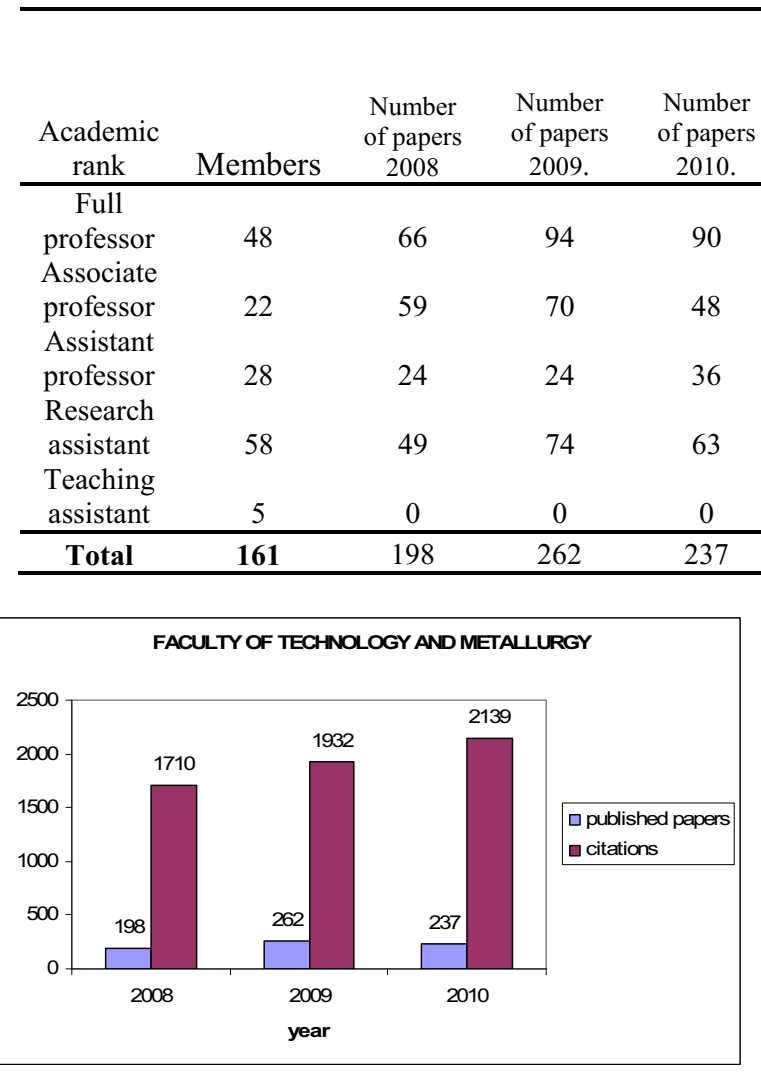

Figure 3. Published papers and citations of professors and other teaching staff at the Faculty of Technology and Metallurgy (period from 2008 to 2010) of citations recorded steady growth. A number of publications is relatively evenly distributed among researchers considering their academic ranks, except for the teaching assistants.

The number of publications and their citations in the post-accreditation period, done by professors and teaching assistants at Technical Faculty in Bor, both in total, and according to the academic ranks, have been shown in Table 4. (www.tf.bor.ac.rs; www.scopus.com).

The graph in Figure 4. shows an 
Table 4. The number of published papers and citations (self-citations excluded) at Technical Faculty in Bor (2008-2010.)

\begin{tabular}{|c|c|c|c|c|c|c|c|c|c|}
\hline $\begin{array}{c}\text { Academic } \\
\text { rank }\end{array}$ & Members & $\begin{array}{c}\text { Number } \\
\text { of papers } \\
2008 \\
\end{array}$ & $\begin{array}{c}\text { Number } \\
\text { of papers } \\
2009 .\end{array}$ & $\begin{array}{c}\begin{array}{c}\text { Number } \\
\text { of papers }\end{array} \\
2010 .\end{array}$ & $\begin{array}{c}\text { Number } \\
\text { of papers } \\
2008- \\
2010 \\
\end{array}$ & $\begin{array}{c}\text { Number } \\
\text { of } \\
\text { citations } \\
2008 \\
\end{array}$ & $\begin{array}{c}\text { Number } \\
\text { of } \\
\text { citations } \\
2009 \\
\end{array}$ & $\begin{array}{c}\text { Number } \\
\text { of } \\
\text { citations } \\
2010 \\
\end{array}$ & $\begin{array}{c}\text { Number } \\
\text { of } \\
\text { citations } \\
2008- \\
2010 \\
\end{array}$ \\
\hline $\begin{array}{c}\text { Full } \\
\text { professor }\end{array}$ & 18 & 40 & 36 & 47 & 123 & 99 & 148 & 198 & 445 \\
\hline $\begin{array}{l}\text { Associate } \\
\text { professor }\end{array}$ & 6 & 5 & 6 & 7 & 18 & 8 & 21 & 11 & 40 \\
\hline $\begin{array}{l}\text { Assistant } \\
\text { professor }\end{array}$ & 17 & 16 & 23 & 29 & 68 & 21 & 47 & 57 & 125 \\
\hline $\begin{array}{l}\text { Research } \\
\text { assistant }\end{array}$ & 30 & 5 & 24 & 31 & 60 & 2 & 7 & 9 & 18 \\
\hline $\begin{array}{l}\text { Teaching } \\
\text { assistant }\end{array}$ & 4 & 0 & 0 & 1 & 1 & 0 & 0 & 0 & 0 \\
\hline Total & 75 & 66 & 89 & 115 & 270 & 130 & 223 & 275 & 628 \\
\hline
\end{tabular}

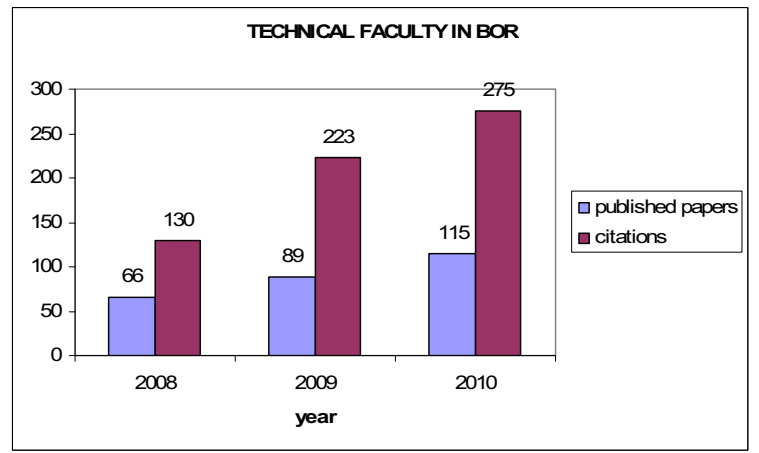

Figure 4. Published papers and citations of professors and other teaching staff at the Technical Faculty in Bor (period from 2008 to 2010)

increasing trend of publications of teaching staff of the Technical Faculty in Bor in the post-accreditation three-year period. The contribution to the creation of such a trend have provided researchers of all academic rank equally, and also the quantitative distribution has been approximately equal.

In Table 5. we have shown the number of papers of professors and teaching staff of Faculty of Electrical Engineering, both the total number and the number of papers by academic ranks. Also, the table shows the number of citations of these researchers, which is very significant in comparison to the number of citations of researchers from other faculties included in this paper (www.etf.bg.ac.rs; www.scopus.com).

Based on the chart shown in Figure 5, there has been a uniform number of publications per year by the teaching staff of Electrical Engineering, followed by an outstanding number of citations. Creation of this trend of publications have been provided by researchers of all academic ranks equally, and also the quantitative distribution is approximately equal.

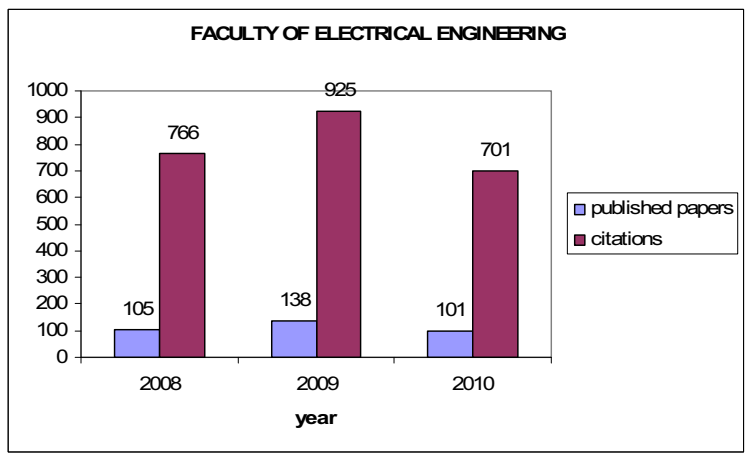

Figure 5. Published papers and citations of professors and other teaching staff at the Faculty of Electrical Engineering (period from 2008 to 2010)

The number of publications and citations in the post-accreditation period, done by 
Table 5. The number of published papers and citations (self-citations excluded) at Faculty of Electrical Engineering (2008-2010.)

\begin{tabular}{|c|c|c|c|c|c|c|c|c|c|}
\hline $\begin{array}{c}\text { Academic } \\
\text { rank }\end{array}$ & Members & $\begin{array}{c}\text { Number } \\
\text { of papers } \\
2008\end{array}$ & $\begin{array}{c}\text { Number } \\
\text { of papers } \\
2009 .\end{array}$ & $\begin{array}{c}\text { Number } \\
\text { of papers } \\
2010 .\end{array}$ & $\begin{array}{c}\text { Number } \\
\text { of papers } \\
2008- \\
2010 \\
\end{array}$ & $\begin{array}{l}\text { Number } \\
\text { of } \\
\text { citations } \\
2008 \\
\end{array}$ & $\begin{array}{l}\text { Number } \\
\text { of } \\
\text { citations } \\
2009 \\
\end{array}$ & $\begin{array}{c}\text { Number } \\
\text { of } \\
\text { citations } \\
2010 \\
\end{array}$ & $\begin{array}{c}\text { Number } \\
\text { of } \\
\text { citations } \\
2008- \\
2010 \\
\end{array}$ \\
\hline $\begin{array}{c}\text { Full } \\
\text { professor }\end{array}$ & 38 & 51 & 57 & 32 & 140 & 566 & 666 & 461 & 1693 \\
\hline $\begin{array}{l}\text { Associate } \\
\text { professor }\end{array}$ & 24 & 20 & 34 & 27 & 81 & 151 & 181 & 160 & 492 \\
\hline $\begin{array}{l}\text { Assistant } \\
\text { professor }\end{array}$ & 38 & 24 & 25 & 21 & 70 & 44 & 65 & 68 & 177 \\
\hline $\begin{array}{l}\text { Research } \\
\text { assistant } \\
\text { Teaching }\end{array}$ & 50 & 10 & 22 & 20 & 52 & 5 & 13 & 12 & 30 \\
\hline assistant & 10 & 0 & 0 & 1 & 1 & 0 & 0 & 0 & 0 \\
\hline Total & 160 & 105 & 138 & 101 & 344 & 766 & 925 & 701 & 2392 \\
\hline
\end{tabular}

Table 6. The number of published papers and citations (self-citations excluded) at Faculty of Transport and Traffic Engineering (2008-2010.)

\begin{tabular}{|c|c|c|c|c|c|c|c|c|c|}
\hline $\begin{array}{l}\text { Academic } \\
\text { rank }\end{array}$ & Members & $\begin{array}{c}\text { Number } \\
\text { of papers } \\
2008\end{array}$ & $\begin{array}{c}\text { Number } \\
\text { of papers } \\
2009 .\end{array}$ & $\begin{array}{c}\text { Number } \\
\text { of papers } \\
2010 .\end{array}$ & $\begin{array}{c}\text { Number } \\
\text { of papers } \\
2008- \\
2010\end{array}$ & $\begin{array}{l}\text { Number } \\
\text { of } \\
\text { citations } \\
2008\end{array}$ & $\begin{array}{l}\text { Number } \\
\text { of } \\
\text { citations } \\
2009\end{array}$ & $\begin{array}{c}\text { Number } \\
\text { of } \\
\text { citations } \\
2010\end{array}$ & 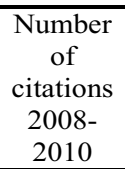 \\
\hline $\begin{array}{c}\text { Full } \\
\text { professor } \\
\text { Associate }\end{array}$ & 28 & 6 & 9 & 15 & 30 & 85 & 135 & 91 & 311 \\
\hline $\begin{array}{l}\text { professor } \\
\text { Assistant }\end{array}$ & 25 & 0 & 6 & 7 & 13 & 10 & 22 & 11 & 43 \\
\hline professor & 14 & 2 & 7 & 7 & 16 & 2 & 4 & 10 & 16 \\
\hline $\begin{array}{c}\text { Research } \\
\text { assistant } \\
\text { Teaching }\end{array}$ & 50 & 5 & 13 & 12 & 30 & 12 & 27 & 18 & 57 \\
\hline assistant & 31 & 0 & 4 & 4 & 8 & 3 & 7 & 8 & 18 \\
\hline Total & 148 & 13 & 39 & 45 & 97 & 112 & 195 & 138 & 445 \\
\hline
\end{tabular}

professors and assistants of the Faculty of Transportation and Traffic Engineering, both by the total number and by academic ranks, is shown in Table 6. (www.sf.bg.ac.rs; www.scopus.com).

The constant increase of the number of papers of professors and assistants of the Faculty of Transport and Traffic Engineering is obvious, but there must be pointed out a relatively small total number of publications, only 97 published papers in the previous three-year period, and it was achieved by 148 researchers. It is also interesting to emphasize the fact that, in 2008, associate professors did not have any published papers

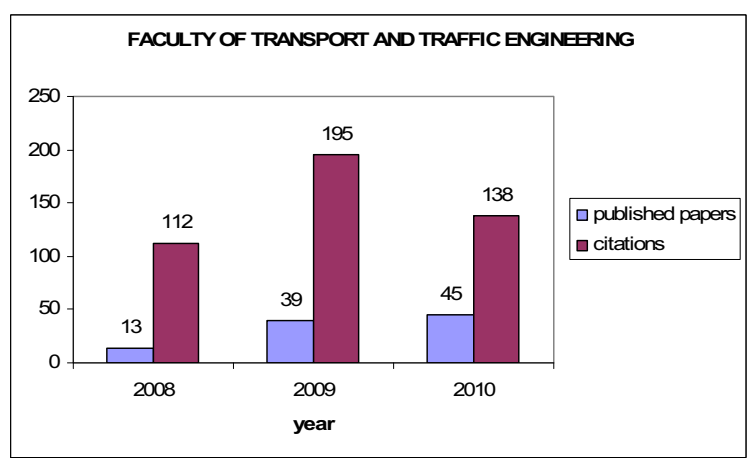

Figure 6. Published papers and citations of professors and other teaching staff at the Faculty of Transport and Traffic Engineering (period from 2008 to 2010) (Figure 6.). 
Table 7. contains data on the number of long period of period can be defined as publications and citations in the post- keeping the constant number of papers rather accreditation period, for professors and other than an increase. On the other hand, a teaching staff of the Faculty of Civil remarkable percentage of work citations has Engineering www.scopus.com). (www.grf.bg.ac.rs; been observed.

A number of published papers and

Table 7. The number of published papers and citations (self-citations excluded) at the Faculty of Civil Engineering (2008-2010.)

\begin{tabular}{|c|c|c|c|c|c|c|c|c|c|}
\hline $\begin{array}{c}\text { Academic } \\
\text { rank }\end{array}$ & Members & $\begin{array}{c}\text { Number } \\
\text { of papers } \\
2008\end{array}$ & $\begin{array}{c}\text { Number } \\
\text { of papers } \\
2009 .\end{array}$ & $\begin{array}{c}\text { Number } \\
\text { of papers } \\
2010 .\end{array}$ & $\begin{array}{c}\text { Number } \\
\text { of papers } \\
2008- \\
2010\end{array}$ & $\begin{array}{l}\text { Number } \\
\text { of } \\
\text { citations } \\
2008\end{array}$ & $\begin{array}{c}\text { Number } \\
\text { of } \\
\text { citations } \\
2009\end{array}$ & $\begin{array}{l}\text { Number } \\
\text { of } \\
\text { citations } \\
2010\end{array}$ & $\begin{array}{c}\text { Number } \\
\text { of } \\
\text { citations } \\
2008- \\
2010\end{array}$ \\
\hline $\begin{array}{c}\text { Full } \\
\text { professor } \\
\text { Associate }\end{array}$ & 20 & 1 & 2 & 0 & 3 & 100 & 137 & 118 & 355 \\
\hline professor & 32 & 4 & 4 & 4 & 12 & 8 & 19 & 12 & 39 \\
\hline $\begin{array}{l}\text { Assistant } \\
\text { professor }\end{array}$ & 33 & 4 & 0 & 4 & 8 & 9 & 7 & 10 & 26 \\
\hline $\begin{array}{l}\text { Research } \\
\text { assistant } \\
\text { Teaching } \\
\text { assistant }\end{array}$ & 61 & 2 & 6 & 7 & 15 & 17 & 12 & 20 & 49 \\
\hline Total & 170 & 11 & 12 & 15 & 38 & 134 & 175 & 160 & 469 \\
\hline
\end{tabular}

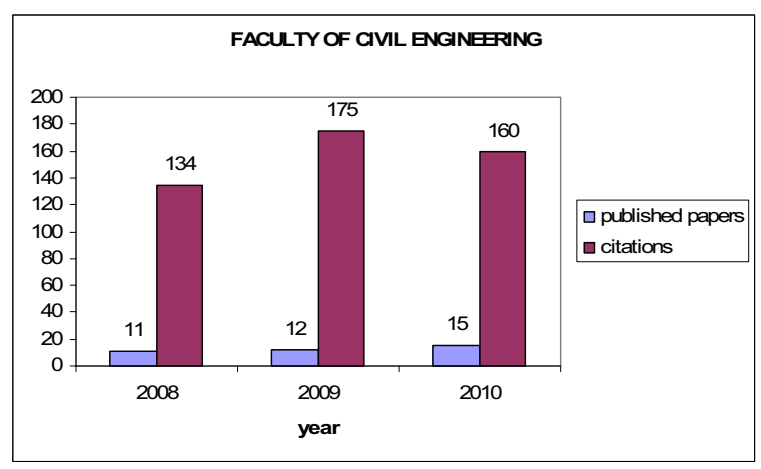

Figure 7. Published papers and citations of professors and other teaching staff at the Faculty of Civil Engineering (period from 2008 to 2010)

The chart shown in Figure 7, shows an interesting trend of published papers done by professors and teaching staff of the Faculty of Civil Engineering, which is desirable. However, the number of 38 publications, in the three year time period-done by 170 researchers, can not be considered satisfactory, so that such a trend in such a citations in the post-accreditation period according to the academic rank, for the Faculty of Mechanical Engineering, are shown in Table 8. (www.mas.bg.ac.rs; www.scopus.com).

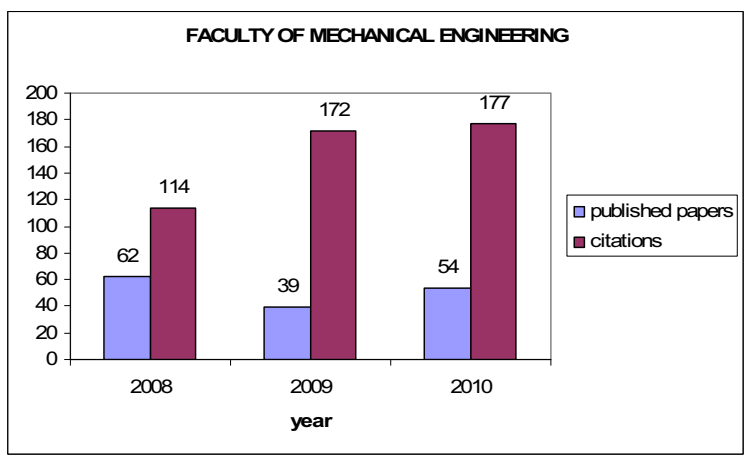

Figure 8. Published papers and citations of professors and other teaching staff at the Faculty of Mechanical Engineering (period from 2008 to 2010)

The number of publications of professors and assistants of Mechanical Engineering 
Table 8. The number of published papers and citations (self-citations excluded) at the Faculty of Mechanical Engineering (2008-2010.)

\begin{tabular}{|c|c|c|c|c|c|c|c|c|c|}
\hline $\begin{array}{c}\text { Academic } \\
\text { rank }\end{array}$ & Members & $\begin{array}{c}\text { Number of } \\
\text { papers } \\
2008 \\
\end{array}$ & $\begin{array}{c}\text { Number of } \\
\text { papers } \\
2009 .\end{array}$ & $\begin{array}{c}\text { Number of } \\
\text { papers } \\
2010 .\end{array}$ & $\begin{array}{c}\text { Number of } \\
\text { papers } \\
2008- \\
2010 \\
\end{array}$ & $\begin{array}{c}\text { Number } \\
\text { of } \\
\text { citations } \\
2008 \\
\end{array}$ & $\begin{array}{c}\text { Number } \\
\text { of } \\
\text { citations } \\
2009 \\
\end{array}$ & $\begin{array}{c}\text { Number } \\
\text { of } \\
\text { citations } \\
2010 \\
\end{array}$ & 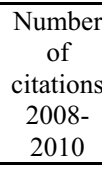 \\
\hline $\begin{array}{c}\text { Full } \\
\text { professor }\end{array}$ & 46 & 23 & 18 & 17 & 58 & 53 & 87 & 78 & 218 \\
\hline $\begin{array}{l}\text { Associate } \\
\text { professor }\end{array}$ & 11 & 17 & 8 & 11 & 36 & 40 & 51 & 50 & 141 \\
\hline $\begin{array}{l}\text { Assistant } \\
\text { professor }\end{array}$ & 26 & 12 & 11 & 15 & 38 & 4 & 24 & 32 & 60 \\
\hline $\begin{array}{l}\text { Research } \\
\text { assistant }\end{array}$ & 41 & 10 & 2 & 10 & 22 & 17 & 10 & 17 & 44 \\
\hline $\begin{array}{l}\text { Teaching } \\
\text { assistant }\end{array}$ & 4 & 0 & 0 & 1 & 1 & 0 & 0 & 0 & 0 \\
\hline Total & 128 & 62 & 39 & 54 & 155 & 114 & 172 & 177 & 463 \\
\hline
\end{tabular}

records some oscillations in the monitored three year period (Figure 8).

Results shown in Table 9. give the possibility for a comparative analysis of scientific and research work of professors and assistants at all eight faculties in the post-accreditation period. It is obvious that a significant difference exists between faculties with regard to the largest number of papers per researcher and the smallest number of papers. The same conclusion can be said when considering the number of citations of the published papers, however, the citations must be seen as the consequence of publications. For this reason, it is logical that these both disparities between the studied variables (number of papers and citations) at the observed faculties, can be solved by increasing the number of publications, in that way quantity can produce quality by increasing citations.

Observing all 1113 professors and associates at studied eight faculties, leads to results that the average number of papers per teacher is 1.71 , while the average number of citations per teacher is 9.93. A clear picture of teachers' scientific contribution is obtained when considering the average number of papers and citations per researcher according to their academic rank (full professor, associate professor, assistant professor, research assistant and teaching

Table 9. The average number of papers and citations per teacher (2008-2010.)

\begin{tabular}{lcc}
\hline \multicolumn{1}{c}{ Faculty } & $\begin{array}{c}\text { Paper/teacher } \\
(2008-2010 .)\end{array}$ & $\begin{array}{c}\text { Citation / teacher } \\
(2008-2010 .)\end{array}$ \\
\hline Faculty of Technology and Metallurgy & 4.33 & 35.91 \\
Technical Faculty in Bor & 3.6 & 8.37 \\
Faculty of Electrical Engineering & 2.15 & 14.95 \\
Faculty of Mining and Geology & 1.46 & 3.88 \\
Faculty of Mechanical Engineering & 1.21 & 3.62 \\
Faculty of Organizational Sciences & 0.72 & 2.43 \\
Faculty of Transport and Traffic Engineering & 0.65 & 3.01 \\
Faculty of Civil Engineering & 0.22 & 2.76 \\
\hline
\end{tabular}


assistant), as shown in Table 10 .

Results shown in Table10. are logical and expected - the number of publications and citation of the researchers is increasing with the title, starting from teaching assistants to full professors. These results without doubt indicate an increase in skills and knowledge with each new academic rank. Of course, as the time goes by experience leads to higher quality publications.

Based on the studied data, it can be observed the obvious correlation between explicit and tacit knowledge, and that some positive results come out from their interdependence. Procedures and guidelines, made by the reform of higher education and accreditation of the Faculty (as a form of explicit knowledge), initiated the increase in the implicit knowledge of teachers that resulted in an explicit form - publications and citations. In this way we have come to the knowledge management in faculties and universities, but it's only the 'initiation' of the knowledge management, because each faculty individually needs to continue this process, which is expected to increase the skills of the researchers.

However, the analysis of the achieved results for the eight studied faculties of the University of Belgrade in the past three-year post-accreditation period, indicates a relatively modest ratio of publications and

Table 10. The average number of papers and the number of citations according to academic ranks

\begin{tabular}{lll}
\hline Academic rank & $\begin{array}{l}\text { Paper / } \\
\text { researcher }\end{array}$ & $\begin{array}{l}\text { Citation / } \\
\text { researcher }\end{array}$ \\
\hline Full professor & 2.64 & 20.16 \\
Associate professor & 2.37 & 18.15 \\
Assistant professor & 1.7 & 6.47 \\
Research assistant & 1.09 & 3 \\
Teaching assistant & 0.15 & 0.19 \\
\hline
\end{tabular}

citations per researcher (professors + associates) at certain faculties. At some faculties the achieved results are related to only one or two researchers. For example, at the RGF, $11.2 \%$ of the total number of publications are achieved by two researchers, and even $45.8 \%$ of citations also by the same two researchers, at the Faculty of Organizational Sciences, $14.9 \%$ of the total number of published papers is a share of the three researchers, and the same researchers accomplished $62.9 \%$ of the total number of citations, while one of them has reached $50.5 \%$ of the total number of citations; at Faculty of Transport and Traffic Engineering, $8.9 \%$ of published papers and $48.9 \%$ of the total number of citations belong to only one researcher; the two researchers at Faculty of Mechanical Engineering achieved $9 \%$ of the total number of papers and $27.6 \%$ of total citations. The uniform distribution of the number of published papers and the number of citations, in relation to all researchers, is the largest at the TMF, and then at ETF and TFB.

The quality of work at the University as a whole, as well as the ranking of universities on the Shanghai list, largely depends on the total number of papers in journals with the impact factor and the number of citations in journals of that category. Such defined rating is accepted in the world today as a global category. And it is an undeniable fact that the interest of all employees at the university, as well as the interest of the founders (the state), is that the University of Belgrade should be found on the Shanghai list as well as be placed among the top 500 best in the world.

To achieve this goal it is necessary that all researchers contribute to everyday activities. The group of technical faculties represents almost $30 \%$ of all members of the University of Belgrade; therefore their contribution is 
very important in achieving this goal - by increasing the number and the quality of publications, to quantify the number of actual citations. So, the quality of scientificresearch work, as a basic supposition of the teaching activity, can be expressed as:

$$
Q=f(C, R)
$$

Where:

Q-the quality of scientific work;

$\mathrm{C}$-the number of citation and

$\mathrm{R}$-the number of published papers.

The dependence of the number of citations on the number of publications per researcher, presents the index of quality of scientific work at each faculty. The index of quality for the past three years and for eight faculties from the studied group is shown in Figure 9.

The obtained results have shown that the index of quality of scientific work at studied faculties in the post-accreditation period is declining in the following way:

TMF - ETF - TFB - RGF - MF - FON $\mathrm{SF}-\mathrm{GF}$.
In addition, the number of citations per researcher increases exponentially with increasing the number of publications per researcher with $\mathrm{R}^{2}=0.801$.

In order to make the summary multicriteria ranking of the impact of examined eight faculties on the quality increase of scientific research and the rating increase of the University of Belgrade on the way towards the Shanghai list, the PROMETHEE II - GAIA analysis, was done. As a ranking criteria, the number of publications in journals with impact factor (weight coefficient 0,4 ) and the number of citations(weight coefficient 0,6 ), were used. In addition to the total result achieved by the universities, which were valued with $55 \%$ in both indicators, there were measured the actual values of obtained results in regular faculties for teachers by the factor of $15 \%$, dean with $20 \%$ and greater delegated members of the expert council (who participate in the verification of the title election and the approval of the doctoral dissertation) by $10 \%$, considering the important influence of these groups in

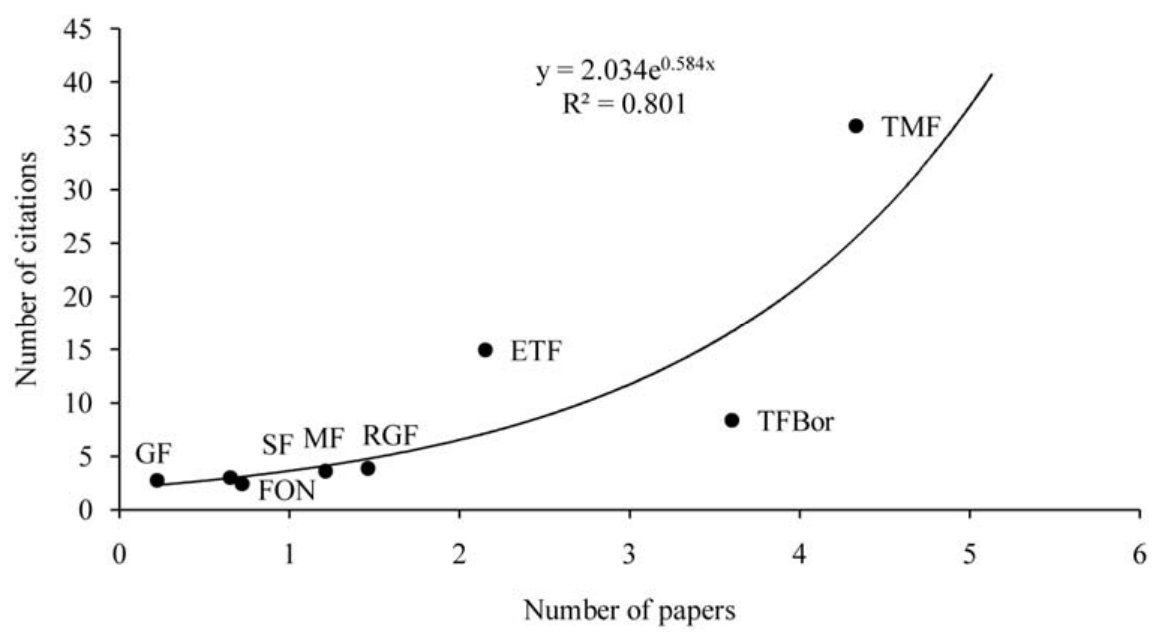

Figure 9. The quality index of scientific work at eight studied technical-technological faculties of Belgrade University expressed as a number of citations in terms of the number of published papers per researcher 
decision making at colleges and quality design of the development of scientific research.

The multicriteria ranking of studied eight faculties was performed based on two factors: the average number of scientific papers and the average number of citations, in 4 categories: category 1-whole faculty, category 2- full professor, category 3- dean and category 4- expert council for scientific field. So, the ranking was done according to 8 criteria, based on data shown in Table 11.

The PROMETHEE II procedure, which is normally done in four steps (Brans, 1982; Brans \& Mareschal, 1994; Macharis et al., 2004; Albadvi et al., 2007; Anand \& Kodali, 2008), is based on comparing pairs of alternatives based on defined functions of preferences and assign weights parameters for each criterion separately. The PROMETHEE method is based on the determination of positive and negative flow for each alternative in relation to outranking relations and in accordance with obtained weight coefficient for each criterion attribute (Brans \& Mareschal, 1994; Macharis et al., 2004). The final ranking of alternatives or a so-called "net flow" is calculated as the difference between positive $(\Phi+)$ and negative $(\Phi-)$ preference flows at any alternatives (Brans, 1982; Anand \& Kodali, 2008). The alternative with the highest net values of the net flow is ranked best etc.

Linear preference function was chosen (type V), with adopted thresholds of indifference and preference $(\mathrm{Q}$ and $\mathrm{P})$ in the zones of $5 \%$ and $30 \%$, respectively. For data analysis the software package Decision Lab 2000, was used and final ranking of alternatives (faculties) is presented in Table 12.

Obtained results, presented in Table 12, very clearly show that the Faculty of Technology and Metallurgy predominates

\section{Table 11. Weight coefficients}

\begin{tabular}{|c|c|c|c|c|c|c|c|c|}
\hline \multirow[b]{3}{*}{ Alternatives } & \multicolumn{8}{|c|}{ Criterions } \\
\hline & \multicolumn{2}{|c|}{ Whole faculty } & \multicolumn{2}{|c|}{ Full professors } & \multicolumn{2}{|c|}{ Dean } & \multicolumn{2}{|c|}{ Expert council } \\
\hline & $\begin{array}{l}\text { Number } \\
\text { of papers }\end{array}$ & $\begin{array}{l}\text { Number of } \\
\text { citations }\end{array}$ & $\begin{array}{l}\text { Number } \\
\text { of papers }\end{array}$ & $\begin{array}{c}\text { Number of } \\
\text { citations }\end{array}$ & $\begin{array}{l}\text { Number } \\
\text { of papers }\end{array}$ & $\begin{array}{c}\text { Number of } \\
\text { citations }\end{array}$ & $\begin{array}{l}\text { Number } \\
\text { of papers }\end{array}$ & $\begin{array}{c}\text { Number of } \\
\text { citation }\end{array}$ \\
\hline $\begin{array}{c}\text { Weight } \\
\text { coefficient } \\
(w j)\end{array}$ & 0.22 & 0.33 & 0.06 & 0.09 & 0.08 & 0.12 & 0.04 & 0.06 \\
\hline Mean value & 1.79 & 9.37 & 2.65 & 20.33 & 4.13 & 63.50 & 5.16 & 26.72 \\
\hline $\begin{array}{c}\text { Std. } \\
\text { deviation }\end{array}$ & 1.47 & 11.54 & 2.33 & 15.75 & 5.22 & 81.01 & 3.96 & 22.47 \\
\hline FON & 0.72 & 2.43 & 1.32 & 10.85 & 0 & 0 & 6.50 & 18.75 \\
\hline RGF & 1.46 & 3.88 & 1.88 & 6.15 & 5.00 & 90.00 & 4.00 & 1.25 \\
\hline TMF & 4.33 & 35.91 & 5.20 & 42.80 & 9.00 & 228.00 & 7.25 & 34.75 \\
\hline TFB & 3.60 & 8.37 & 6.80 & 24.72 & 14.00 & 113.00 & 13.00 & 44.00 \\
\hline ETF & 2.15 & 14.95 & 3.60 & 44.55 & 0 & 73.00 & 5.50 & 45.00 \\
\hline SF & 0.65 & 3.01 & 1.07 & 11.10 & 5.00 & 0 & 2.25 & 60.25 \\
\hline GF & 0.22 & 2.76 & 0.15 & 17.75 & 0 & 0 & 0 & 0 \\
\hline MF & 1.21 & 3.62 & 1.20 & 4.73 & 0 & 4.00 & 2.75 & 9.75 \\
\hline
\end{tabular}


Table 12. Final ranking

\begin{tabular}{ccccc}
\hline Faculty & $\boldsymbol{\Phi}^{+}(\mathbf{a})$ & $\boldsymbol{\Phi}^{-}(\mathbf{a})$ & $\mathbf{\Phi}(\mathbf{a})$ & Rank \\
\hline FON & 0.1326 & 0.7718 & -0.6393 & 7 \\
RGF & 0.4571 & 0.4670 & -0.0098 & 4 \\
TMF & $\boldsymbol{0 . 9 1 9 3}$ & $\mathbf{0 . 0 5 0 1}$ & $\mathbf{0 . 8 6 9 2}$ & $\boldsymbol{1}$ \\
TFB & 0.8101 & 0.1649 & 0.6452 & 2 \\
ETF & 0.7055 & 0.2656 & 0.4400 & 3 \\
SF & 0.2375 & 0.6324 & -0.3949 & 6 \\
GF & 0.1248 & 0.8048 & -0.6800 & 8 \\
MF & 0.3409 & 0.5712 & -0.2303 & 5 \\
\hline
\end{tabular}

over other tested faculties, and that the alternatives - Faculty of Organizational Sciences and Faculty of Civil Engineering are the worst ranked on the list of eight studied engineering faculties of Belgrade University.

On the other hand, the GAIA plane, presented in Figure 10, as a visual aid in the decision-making process, clearly indicates the existence of clusters of certain alternatives, which have the similar behavior. Therefore, the GAIA plane confirms the existence of certain characteristics of the alternatives (represented by triangles) for the defined 8 criteria (represented by squares). First of all, we should point out that the ranking model has achieved a high degree of representation of data in the GAIA plane, through data extraction by the principal component analysis (PCA) of $78.65 \%$, which means that about $21.35 \%$ of the total explained variation has been lost by projection.

In Fig.10, within the GAIA plane, three

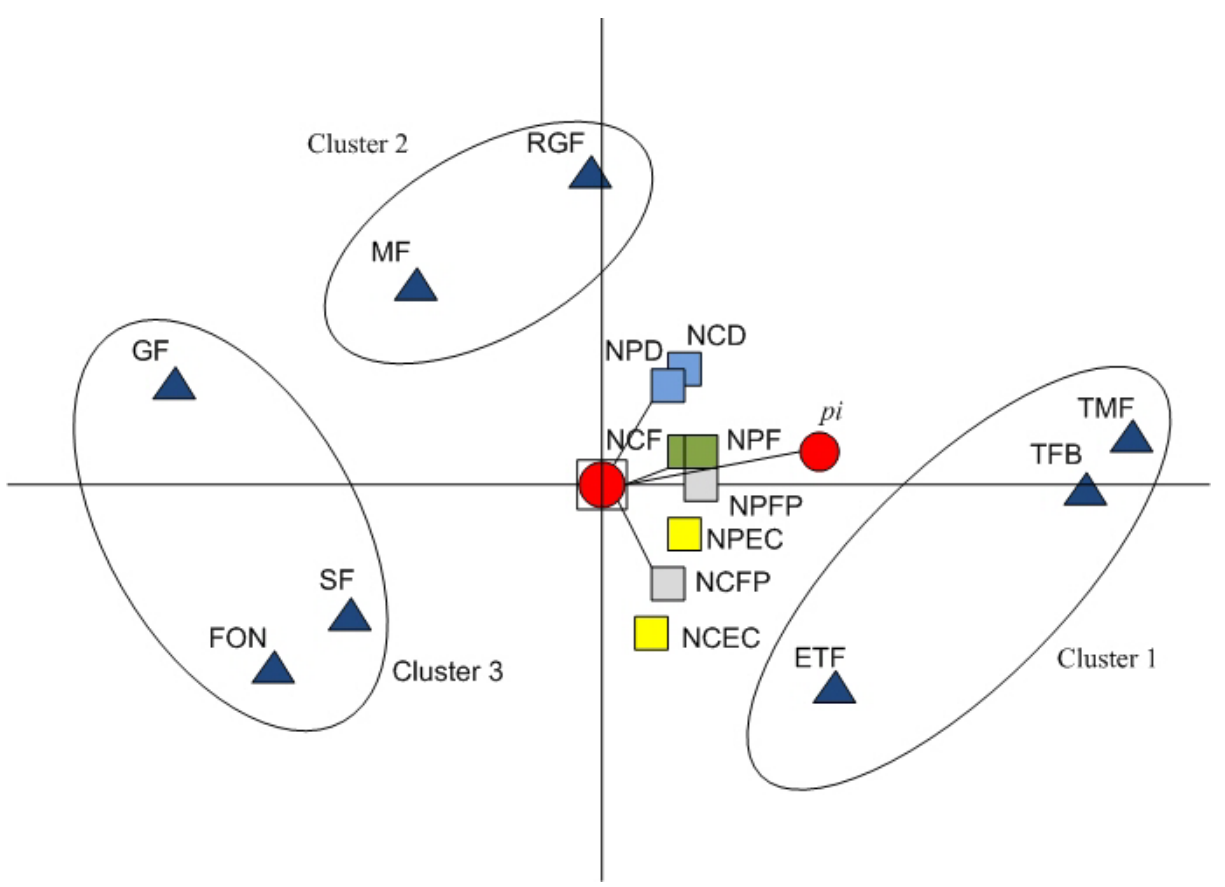

Figure 10. The GAIA plane 
independent clusters are marked, containing alternatives with similar characteristics in relation to the given criteria. Also, the orientation of defined clusters towards certain criteria, indicates that the alternatives from that group are good according to this criterion. It is clear that the faculties from the cluster 1 (TMF, TFB and ETF), are located in the direction of all 8 criteria axes, which overlaps with the result of PROMETHEE II rankings, since these are the first three ranked faculties. On the other hand, the positions of clusters 2 and 3 , indicate that the alternatives from these groups significantly differ in quality for a given rating, compared to the alternatives from the cluster 1 . This is also supported by the orientation of the socalled, decision stick (pi), which is directed at the best ranked faculty of Technology and Metallurgy and opposite directed in relation to cluster 3, where the least favorable alternative placed GF, FON and SF, respectively. It should be emphasized that the quality of the performed ranking is reflected in the fact that there is no conflict among the given criteria, which can be seen graphically both as the opposite orientation of all the eight criteria, and by relatively the same length of criteria axis in relation to the coordinate beginning, indicating the equal importance of the defined criteria, that is, a good distribution of assigned weight parameters.

\section{CONCLUSION}

Faculties and universities, as well as other scientific and educational institutions should be an example of knowledge management. If we are talking about reforms, which include positive steps, faculties should be those institutions that are able to implement planned changes. In particular, implemented within the faculty, accreditation of higher education reform will lead to a better quality of studies. This can be achieved by improving skills and increasing knowledge of professors and assistants. In this way, the creation of changes in the explicit knowledge (which includes rules, policies, procedures, etc.) will trigger changes in the personal skills of teachers and assistants. Each of them, by a learning process, improves the quality of teaching. Generally speaking, all members of the organization in this way initiate process of organizational learning. So, only in these circumstances we can talk about the knowledge management within the faculty, that is, it is possible to talk about the effects of one kind of knowledge on the other, about their actions and reactions.

Practically, the increase of the level of knowledge and skills of professors and assistants can be measured, inter alia, with an increased number of published scientific papers. In addition to quantitative indicators, it is necessary to consider the qualitative indicators, like the quality of publications that reflect the number of citations. In this way this paper examined the quality of running processes at studied faculties at the University of Belgrade. If we consider that there is a steady upward trend in publications, it can be said that in these schools the knowledge management exists, that the reform process works, and consequently, the teaching staff who are constantly improving and upgrading their competencies and knowledge, will eventually provide their students with a higher level classes. Finally, a qualitative indicator of the knowledge management, ie. number of citations, is also such that we can say for sure that the increased involvement of researchers from the studied University 
delivers high quality results.

The indisputable need of all stakeholders at the University of Belgrade (teachers and students) and the State as a key stakeholder is the University of Belgrade to be placed on the Shanghai list and to take a better position among the top 500 universities in the world. Part of the academic community in Serbia believes that it is also one of the vital national interests. Unfortunately, there is part of the community at the University that has an opposite opinion.

The achieved improvements, which are evident in the post-accreditation period at most technical-technological faculties of Belgrade University, suggest that the process of approaching the Shanghai list started with certain resistance of part of the University which do not react to the fact that changes have already become part of reality.

\title{
АНАЛИЗА РЕЗУЛТАТА НАУЧНО-ИСТРАЖИВАЧКОГ РАДА ТЕХНИЧКО - ТЕХНОЛОШКИХ ФАКУЛТЕТА УНИВЕРЗИТЕТА У БЕОГРАДУ У ПОСТАКРЕДИТАЦИОНОМ ПЕРИОДУ
}

\author{
Милица Арсић*, Ненад Милијић, Драгана Живковић, \\ Ђорђе Николић и Живан Живковић \\ Универзитет у Београду, Технички факултет у Бору, \\ Војске Југославије 12, 19210 Бор, Србија
}

\begin{abstract}
Извод
У овом раду је презентована анализа остварених резултата научно-истраживачког рада техничко-технолошких факултета Универзитета у Београду у постакредатационом периоду (2008-2010. година), мерених преко броја публикованих радова у часописима са импакт фактором и остварених цитата, према SCOPUS бази података. Број радова и број цитата у разматраном трогодишњем периоду презентован је по категоријама наставника за сваки факултет посебно. Индекс квалитета рачунат је као однос цитираних и публикованих радова за сваки факултет посебно и прерачунат је по истраживачу, чиме је елиминисан утицај величине факултета на остварени резултат. Вишектритеријумском PROMETHEE II - GAIA анализом дефинисани су и кластери факултета, чиме је одређен значај оствареног доприноса техничких факултета, Универзитета у Београду, на путу ка Шангајској листи 500 прворангираних универзитета у свету.
\end{abstract}

Кључне речи: научно-истраживачки рад, техничко-технолошки факултети, Универзитет у Београду, SCOPUS, PROMETHEE II - GAIA

Announcement: The authors feel indebted to the company Visual Decision Inc. Montreal, Canada; for software package Decision Lab 2000 provided to them free of charge. 


\section{References}

Albadvi, A., Chaharsooghi, S. K., \& Esfahanipour, A. (2007) Decision making in stock trading: An application of PROMETHEE. European Journal of Operational Research, 177(2): 673-683.

Anand, G., \& Kodali, R. (2008) Selection of lean manufacturing systems using the PROMETHEE. Journal of Modelling in Management, 3(1): 40-70.

Brans, J.P. (1982). L'ingénièrie de la décision; Elaboration d'instruments d'aide à la décision. La méthode PROMETHEE. Pp. 183-213 in R. Nadeau, \& M. Landry (Eds.), L'aide à la décision: Nature, Instruments et Perspectives d'Avenir. Presses de l'Université Laval, Québec, Canada.

Brans, J.P., \& Mareschal, B. (1994) The PROMCALC \& GAIA decision support system for multicriteria decision aid. Decision Support Systems, 12: 297-310.

Dagli, G., Silman, F., \& Birol, C. (2009) A Qualitative Research Regarding the University Administrators' Capacity to Use of Management Information Tools. Procedia Social and Behavioral Sciences, 1: 24802490.

Garvin, D.A. (1993) Building a learning organization. Harvard Business Review 71(4): 78-92.

Klobas, J.E. (1997). Information services for new millennium organisations: librarians and knowledge management. Pp. 39-64 in Raitt, D. (Ed.), Libraries for the New Millennium: Implications for Managers. Library Association, London.

Macharis, C., Springael, J., De Brucker, K., \& Verbeke, A. (2004) PROMETHEE and AHP: The design of operational synergies in multicriteria analysis. Strengthening PROMETHEE with ideas of AHP. European Journal of Operational Research, 153(2): 307-317.
Numprasertchai, S., \& Igel, B. (2005) Managinig knowledge through collaboration: multiple case studies of managing research in university laboratories in Thailand. Technovation, 25: 1173-1182.

Rosell, C., \& Agrawal, A. (2009) Have university knowledge flows narrowed? Evidence from patent data. Research Policy, 38: 1-13.

Van Looy, B., Callaert, J., \& Debackere, K. (2006) Publication and patent behavior of academic researchers: Conflicting, reinforcing or merely co-existing? Research Policy, 35: 596-608.

Wijetunge, P. (2002) Adoption of Knowledge Management by the Sri Lankan University librarians in the light of the National Policy on University Education. International Journal of Educational Development, 22: 85-94.

Živković, D., Živković, Ž., Manasijević, D., \& Kostadinović, M. (2010) Investigation of the knowledge combination interrelations between SMEs and consumer/supplier network. Serbian Journal of Management, 5(2): 261-269.
Web references:
www.fon.bg.ac.rs www.rgf.bg.ac.rs www.tmf.bg.ac.rs www.tf.bor.ac.rs www.etf.bg.ac.rs www.sf.bg.ac.rs www.grf.bg.ac.rs www.mas.bg.ac.rs www.scopus.com 